\title{
Studi Eksperimen Pengaruh Kecepatan Udara Pengering Inlet Chamber pada Swirling Fluidized Bed Dryer Terhadap Karakteristik Pengeringan Batubara
}

\author{
Dicky Permana dan Prabowo \\ Jurusan Teknik Mesin, Fakultas Teknologi Industri, Institut Teknologi Sepuluh Nopember (ITS) \\ Jl. Arief Rahman Hakim, Surabaya 60111 Indonesia \\ e-mail: prabowo@me.its.ac.id
}

\begin{abstract}
Abstrak-Energi listrik merupakan energi yang dominan dibutuhkan untuk kehidupan manusia. Salah satu sumber penghasil listrik yaitu Pembangkit Listrik Tenaga Uap (PLTU). Bahan bakar utama PLTU pada umumnya adalah batubara. Ketika digunakan batubara kalori rendah maka dibutuhkan suplai batubara yang lebih banyak sehingga pulverizer akan bekerja ekstra. Masalah akan timbul ketika pulverizer rusak, dimana suplai batubara ke boiler akan berkurang yang menyebabkan kapasitas produksi listrik menurun. Untuk menghidari hal tersebut dilakukan proses pengeringan. Fluidized bed dryer merupakan salah satu teknologi dari proses proses pengeringan yang bisa digunakan untuk meningkatkan kalori batubara dengan mengurangi moisture content yang ada dalam batubara. Penelitian ini dilakukan dengan studi eksperimen menggunakan alat percobaan yaitu swirling fluidized bed coal dryer. Udara panas dengan temperatur $45^{\circ} \mathrm{C}$ dihembuskan oleh blower ke dalam chamber yang divariasikan pada kecepatan $2 \mathrm{~m} / \mathrm{s}, 2,5 \mathrm{~m} / \mathrm{s}$ dan $3 \mathrm{~m} / \mathrm{s}$ melewati distributor blade sudut $2^{\circ}$ sehingga kontur udara menjadi swirl. Pengambilan data dilakukan dengan menimbang massa sampel batubara basah setiap 1 menit sebanyak 15 kali dan 2 menit sebanyak 8 kali sehingga total waktu pengeringan 31 menit. Percobaan dilakukan dengan beban pengeringan 600 gram dan ukuran partikel $6 \mathrm{~mm}$, dilanjutkan dengan pengovenan temperatur $105^{\circ} \mathrm{C}$ selama 180 menit untuk mencari berat kering berdasarkan standar ASTM D 3173. Dari hasil eksperimen diketahui bahwa pada kecepatan $2 \mathrm{~m} / \mathrm{s}, 2,5 \mathrm{~m} / \mathrm{s}$ dan $3 \mathrm{~m} / \mathrm{s}$ didapat drying rate batubara berturut-turut sebesar $1,9806 \%$ per menit, 2,638 $\%$ per menit dan $3,1182 \%$ per menit. Untuk koefisien perpindahan massa berturut-turut sebesar $0,065203 \mathrm{~m} / \mathrm{s}$, $0,072052 \mathrm{~m} / \mathrm{s}$ dan $0,078264 \mathrm{~m} / \mathrm{s}$.
\end{abstract}

Kata Kunci-Perpindahan Panas dan Massa, Psychrometric Chart, Swirling Flidized Bed Coal Dryer.

\section{Pendahuluan}

$\mathrm{E}$ nergi listrik merupakan energi yang dibutuhkan oleh peralatan listrik untuk menghasilkan bentuk energi yang lain. Energi listrik termasuk bentuk energi sekunder yang dihasilkan dari proses konversi sumber energi primer seperti energi surya, energi angin, panas bumi, minyak bumi, gas dan batubara. Salah satu sumber penghasil listrik yaitu pembangkit listrik tenaga uap (PLTU) yang bekerja dengan mengkonversi energi kimia menjadi energi listrik. Pada umumnya PLTU menggunakan batubara sebagai bakar bakar utama. Hal ini dikarenakan batubara tersedia cukup banyak di Indonesia.
Karakteristik pembakaran batubara dalam sebuah pembangkit listrik tenaga uap dipengaruhi oleh beberapa hal yaitu kualitas batubara, batasan yang ditentukan oleh desain boiler, posisi burner, konfigurasi fisik dan perpindahan panas dalam boiler serta kondisi operasional. Dengan adanya pengaruh tersebut maka PLTU mendesain boiler sesuai dengan spesifikasi tertentu. Kurangnya pasokan batubara yang sesuai dengan spesifikasi menyebabkan digunakannya batubara jenis lain yang kualitasnya tidak memenuhi spesifikasi. Hal ini dapat mempengaruhi optimalisasi dan efisiensi PLTU dalam menghasilkan listrik. Maka dari itu diperlukan upaya untuk meningkatkan kalori pada batubara dengan proses pengeringan. Proses ini bertujuan untuk mengurangi kadar air pada batubara sehingga nilai kalorinya dapat meningkat.

Salah satu peneliti yang melakukan eksperimen dengan metode pengeringan yaitu Edward K Levi yang berjudul "Use Of Coal Drying To Reduce Water Consumed In Pulverized Coal Power Plant". Penelitian dilakukan dengan mengalirkan udara melewati pemanas menuju ke drying chamber. Hasil yang didapat dari eksperimen tersebut diantaranya yaitu dari variasi kecepatan $0,9 \mathrm{~m} / \mathrm{s}$ sampai $1,7 \mathrm{~m} / \mathrm{s}$, kecepataan 1,7 memiliki nilai drying rate paling besar dan dari variasi temperatur $43^{\circ} \mathrm{C}$ sampai $66^{\circ} \mathrm{C}$, temperatur $66^{\circ} \mathrm{C}$ memiliki nilai drying rate paling besar.

\section{MEtodologi}

\section{A. Metode Eksperimen}

Berikut merupakan skema alat eksperimen swirling fluidized bed coal dryer ditunjukkan pada gambar 1 .

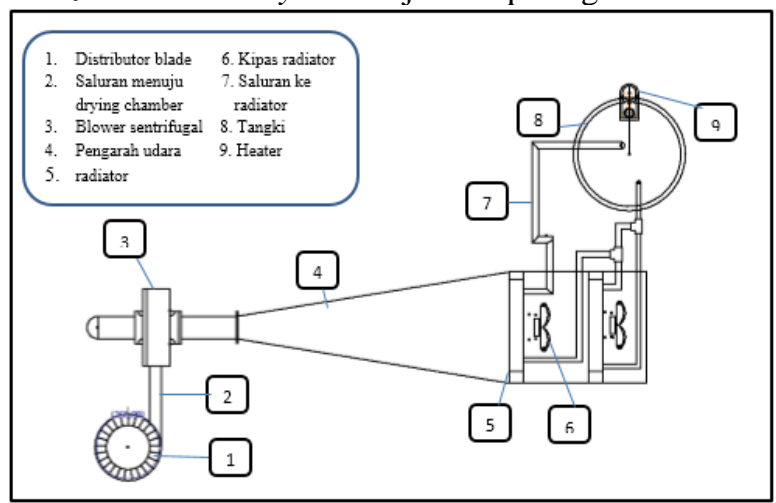

Gambar 1. Skema alat Swirling fluidized bed coal dryer 
Cara kerja alat pada gambar 1 yaitu dengan memanaskan air yang ada didalam tangki menggunakan heater dan kompor hingga suhu air mencapai $72^{\circ} \mathrm{C}$. Air panas dialirkan menuju radiator yang berfungsi sebagai penukar panas dengan udara. Kemudian udara dihembuskan ke dalam saluran menuju drying chamber menggunakan blower sentrifugal. Terdapat distributor blade pada drying chamber dengan sudut $20^{\circ}$ yang berfungsi untuk membentuk aliran swirl. Dengan terbentuknya aliran swirl diharapkan proses perpindahan panas dan massa terjadi secara maksimal sehingga proses pengeringan dapat berlangsung lebih cepat. Pada penelitian ini akan ditinjau dari sisi udara dan sisi batubara sehingga diperlukan beberapa data yaitu temperatur dry bulb in dan out, relative humidity in dan out serta berat batubara basah dan kering.

Pada eksperimen ini terdapat beberapa titik pengukuran seperti pada gambar 2 sebagai berikut.

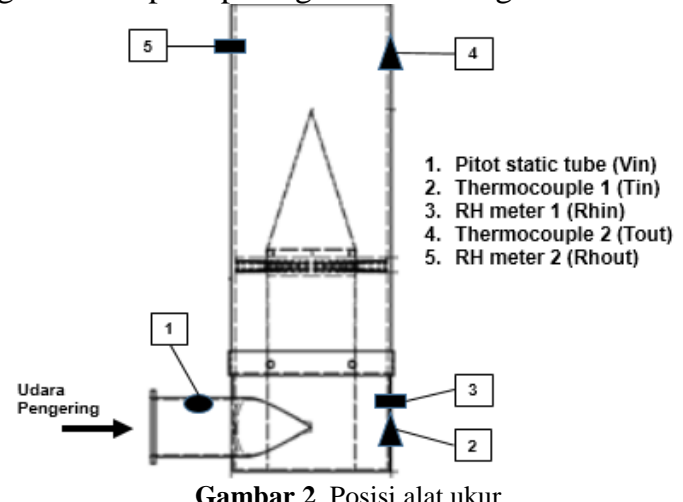

Selama proses pengujian tersebut terdapat parameterparameter yang diukur yaitu :

1. Pitot static tube untuk mengukur tekanan udara yang nantinya digunakan untuk menentukan kecepatan inlet chamber.

2. Thermocouple 1 untuk mengukur temperatur dry bulb inlet chamber (Tin).

3. RH meter 1 untuk mengukur relative humidity inlet chamber (RHin).

4. Thermocouple 2 untuk mengukut temperatur dry bulb outlet chamber (Tout).

5. RH meter 2 untuk mengukur relative humidity outlet chamber (RHout).

\section{B. Prosedur Eksperimen}

Eksperimen dilakukan dengan memvariasikan kecepatan udara pengering inlet chamber sebesar $2 \mathrm{~m} / \mathrm{s}$, $2,5 \mathrm{~m} / \mathrm{s}$ dan $3 \mathrm{~m} / \mathrm{s}$. Kecepatan ini diukur dengan mengkalibrasi pitot static tube dengan manometer dan different presure transmitter dan DAQ data logger untuk mendapatkan kecepatan yang sesuai pada selongsong sebelum masuk ke inlet chamber. Berat batubara yang digunakan sebesar 600 gram dan ukuran $\pm 6 \mathrm{~mm}$ dengan sudut blade $20^{\circ}$. Pengaturan kecepatan udara pengering dilakukan dengan mengatur kecepatan putaran dari blower, dimana putaran blower dapat diatur dengan voltage regulator.

Pengambilan sampel batubara dilakukan setiap 1 menit sebanyak 15 kali dan 2 menit sebanyak 8 kali, dimana saat dilakukan pengambilan sampel nilai RH dicatat. Untuk temperatur akan dicatat secara otomatis menggunakan data logger yang dihubungkan ke thermocouple. Setiap sampel batubara akan ditimbang untuk mencari berat basah. Kemudian sampel dioven menggunakan oven electrik selama 180 menit dengan temperatur $105^{\circ} \mathrm{C}$ (standar pengeringan menurut ASTM D5142). Sampel yang sudah dioven selanjutnya ditimbang untuk mencari berat kering sehingga akan didapatkan beberapa data yaitu RH inlet, RH outlet, temperatur inlet, temperatur outlet, berat basah dan berat kering dari batubara.

\section{Analisa Perhitungan dari Sisi Udara}

Pshychrometric chart adalah gambaran dari sifat-sifat termodinamika dari udara basah dan variasi proses sistem penyegaran udara dan siklus sistem penyegaran udara. Analisa dilakukan dengan memplotkan data relative humidity inlet, relative humidity outlet, temperetur dry bulb inlet dan temperatur dry bulb outlet yang didapat selama proses pengeringan.

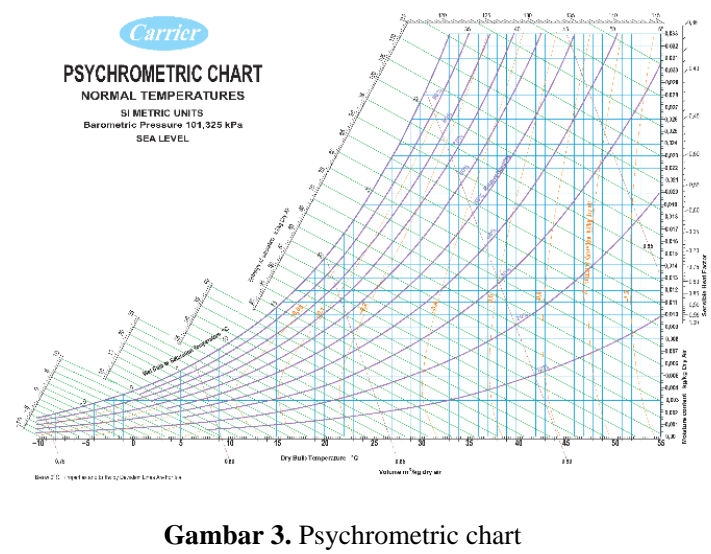

Perhitungan laju alir massa dapat dhitung dengan persamaan berikut :

$\dot{\mathrm{m}}=\rho_{\text {udara }} \cdot v \cdot A_{\text {selongsong }}$

Massa jenis udara pengering inlet dan ratio humidity didapat dengan memplot data nilai $\mathrm{RH}$ inlet dan $\mathrm{Tdb}$ inlet dalam psychrometric chart. Luasan selongsong merupakan luasan penampang dari saluran blower ke drying chamber. Perhitungan selisih ratio humidity antara inlet dengan outlet yang terbaca selama proses pengeringan dapat dihitung dengan persamaan berikut :

$\Delta \omega=\omega_{t}-\omega_{\text {inlet }}$

Untuk mendapatkan nilai massa udara kering dapat menggunakan persamaan sebagai berikut [4]:

$m_{\text {udara kering }}=\dot{\mathrm{m}}$. interval pengeringan

Sehingga dapat dicari jumlah massa uap air yang terserap oleh udara dengan menggunakan persamaan berikut :

$m_{\text {uap air }}=\Delta \omega \times m_{\text {udara } \text { kering }}$

\section{Analisa Perhitungan dari Sisi Batubara}

Perhitungan dari sisi batubara menggunakan data berat basah dan berat kering hasil dari eksperimen. Data ini digunakan untuk mencari moisture content pada batubara. Perhitungan dapat dilakukan dengan menggunakan persamaan sebagai berikut:

$M C=\frac{m_{\text {basah }}-m_{\text {kering }}}{m_{\text {basah }}}$

Dari persamaan di atas , Maka drying rate yang terjadi dapat dihitung dengan persamaan sebagai berikut [4]:

Drying rate $=\frac{M C_{a w a l}-M C_{a k h i r}}{\Delta t}$ 


\section{HASIL DAN PEMBAHASAN}

Pada penelitian eksperimen swirling fluidized bed coal dryer dengan variasi kecepatan udara pengering inlet chamber didapatkan hasil analisa untuk mengetahui pengaruh kecepatan terhadap karakteristik pengeringan batubara. Dari sisi udara didapatkan grafik relative humidity, temperatur outlet dry bulb dan selisih ratio humidity dengan menggunakan psychrometric chart. Dari sisi batubara didapatkan grafik moisture content dan drying rate. Sub-bab A sampai D menjelaskan mengenai analisa dari sisi udara dan sub-bab $E$ sampai $F$ menjelaskan mengenaik analisa dari sisi batubara.

\section{A. Diagram Psychrometric Hasil Data Pengeringan}

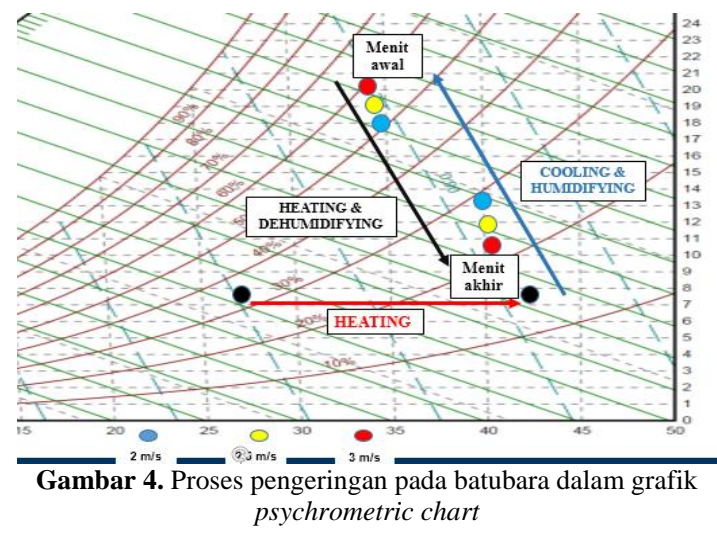

Pada gambar 4 terlihat proses pengeringan yang terjadi pada batubara, yang mengalami beberapa fase yaitu yang pertama proses pemanasan atau (heating). Pada fase ini udara ambient akan dipanaskan pada heat exchanger yang tersusun secara seri. Hal ini dimaksudkan agar udara yang dihasilkan mendapat panas yang maksimal sehingga dapat lebih cepat digunakan untuk proses pengeringan. Kedua yaitu fase cooling and humidifying, dimana ini terjadi saat batubara dimasukkan kedalam chamber yang mengakibatkan suhu udara mengalami penurunan karena terjadi perpindahan panas antara udara dengan batubara. Tidak hanya terjadi proses perpindahan panas, namun diiringi juga proses perpindahan massa. Proses perpindahan massa uap air menuju udara pengering. Seiring berjalannya waktu temperatur udara dan batubara akan mencapai keseimbangan sehingga akan terjadi fase selanjutnya yaitu heating dan humidifying. Humidifying adalah proses penambahan kandungan uap air pada udara sehingga terjadi kenaikan entalpi dan ratio humidity. ketika temperatur udara semakin naik seiring berjalannya waktu, maka nilai dari relative humidity akan turun.

B. Pengaruh Kecepatan Terhadap Relative Humidity Fungsi Drying Time

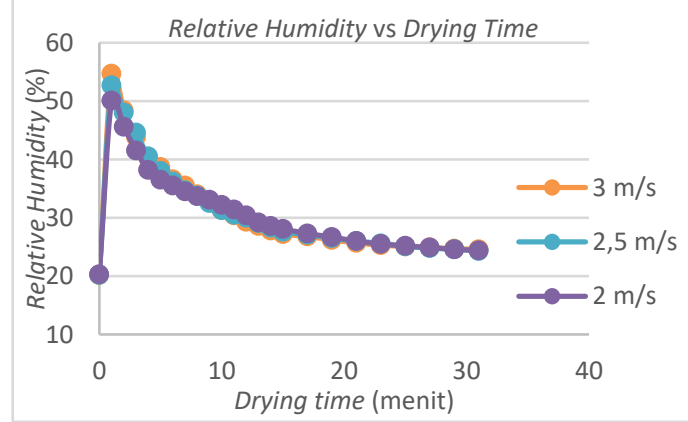

Gambar 5. Grafik pengaruh kecepatan terhadap relative humidity fungsi drying time
Relative humidity adalah istilah yang digunakan untuk menggambarkan jumlah uap air yang terkandung di dalam campuran air-udara dalam fase gas. Trendline grafik menunjukkan besarnya nilai relative humidity pada udara keluar chamber dengan variasi kecepatan yang digunakan yaitu $2 \mathrm{~m} / \mathrm{s}, 2,5 \mathrm{~m} / \mathrm{s}$ dan $3 \mathrm{~m} / \mathrm{s}$. Nilai perubahan relative humidity pada kecepatan $2 \mathrm{~m} / \mathrm{s}$ dari $50,1 \%$ pada menit ke-1 menuju $24,4 \%$ pada menit ke31. Nilai perubahan relative humidity pada kecepatan 2,5 $\mathrm{m} / \mathrm{s}$ dari $52,7 \%$ pada menit ke-1 menuju $24,3 \%$ pada menit ke-31. Nilai perubahan relative humidity pada kecepatan $3 \mathrm{~m} / \mathrm{s}$ dari $54,7 \%$ pada menit ke-1 menuju 24,6 $\%$ pada menit ke-31. Nilai relative humidity mengalami penurunan secara signifikan pada menit-menit awal kemudian cenderung konstan pada menit akhir. Nilai relative humidity untuk setiap variasi kecepatan akan cenderung mendekati nilai relative humidity awal dari udara pengering.

Dari gambar 5 dapat dilihat bahwa kecepatan $3 \mathrm{~m} / \mathrm{s}$ memiliki nilai relative humidity terbesar diikuti kecepatan $2,5 \mathrm{~m} / \mathrm{s}$ dan $2 \mathrm{~m} / \mathrm{s}$. Nilai relative humidity pada kecepatan $3 \mathrm{~m} / \mathrm{s}$ mangalami penurunan terbesar pada menit awal sehingga pada menit ke-10 menunjukkan trenline grafik yang sejajar dengan trendline relative humidity pada kecepatan $2,5 \mathrm{~m} / \mathrm{s}$ dan $2 \mathrm{~m} / \mathrm{s}$. Seharusnya pada menit awal-awal nilai relative humidity pada kecepatan 3 memiliki nilai penurunan paling tinggi sehingga pada suatu waktu laju perpindahan massa dari kecepatan yang lebih tinggi akan menjadi lebih kecil karena mampu mengeringkan lebih cepat. Hal ini akan menyebabkan uap air pada batubara akan lebih cepat habis saat menggunakan kecepatan yang lebih tinggi.

\section{Pengaruh Kecepatan Terhadap Temperatur Udara Keluar Chamber Fungsi Drying Time}

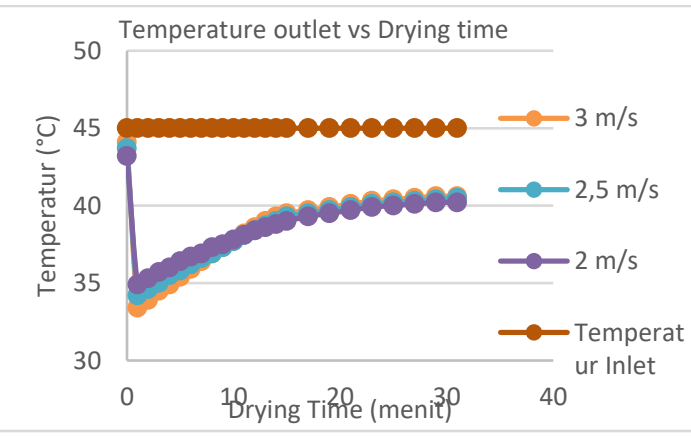

Gambar 6. Grafik pengaruh kecepatan terhadap temperatur udara keluar chamber fungsi drying time

Pada gambar 9 dapat dilihat bahwa trendline untuk masing-masing variasi kecepatan menunjukkan penurunan di menit awal kemudian naik hingga menit akhir. Pada kecepatan $3 \mathrm{~m} / \mathrm{s}$ memiliki temperatur sebesar $33,4{ }^{\circ} \mathrm{C}$ pada menit ke-1 dan memiliki temperatur sebesar $40,6{ }^{\circ} \mathrm{C}$ pada menit ke-31, kecepatan $2,5 \mathrm{~m} / \mathrm{s}$ memiliki temperatur sebesar $34,2^{\circ} \mathrm{C}$ pada menit ke-1 dan memiliki temperatur sebesar $40,5{ }^{\circ} \mathrm{C}$ pada menit ke-31, serta kecepatan $2 \mathrm{~m} / \mathrm{s}$ memiliki temperatur sebesar 34,9 ${ }^{\circ} \mathrm{C}$ pada menit ke-1 dan memiliki temperatur sebesar 40,2 ${ }^{\circ} \mathrm{C}$ pada menit ke-31.

Trendline grafik menunjukan penurunan udara pengering di menit awal dan naik seiring bertambahnya waktu yang dikarenakan adanya proses perpindahan panas antara udara pengering dengan batubara. Pada awal proses pengeringan, panas yang diterima batubara cukup besar karena perbedaan antara permukaan 
batubara dengan udara pengering cukup besar. Setelah beberapa waktu temperatur permukaan batubara akan bartambah sehingga menyebabkan selisih temperatur antara udara pengering dan batubara semakin kecil. Hal ini menyebabkan proses perpindahan panas yang terjadi akan semakin kecil.

\section{Pengaruh Kecepatan Terhadap Selisih Humidity} Ratio Fungsi Drying Time

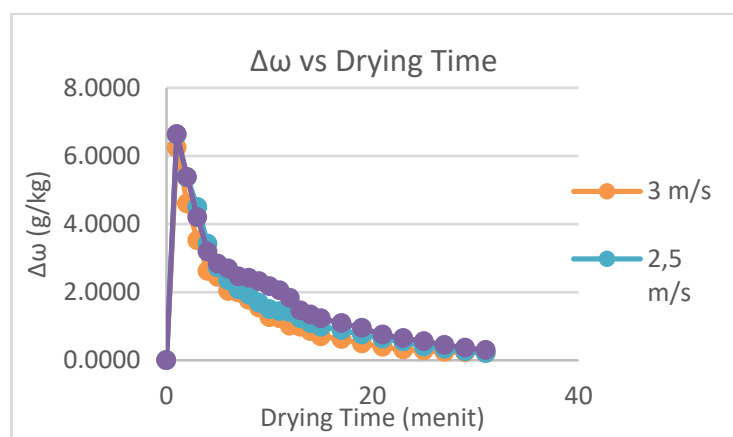

Gambar 7. Grafik pengaruh kecepatan terhadap selisih humidity ratio fungsi drying time

Pada gambar 7 terlihat grafik humidity ratio fungsi drying time dengan variasi kecepatan $3 \mathrm{~m} / \mathrm{s}, 2,5 \mathrm{~m} / \mathrm{s}$ dan $2 \mathrm{~m} / \mathrm{s}$. Humidity ratio adalah massa air yang terkandung dalam setiap kilogram udara kering. Humidity ratio udara ditentukan berdasarkan $1 \mathrm{~kg}$ udara kering. Grafik di atas memiliki trendline yang menurun setiap variasi kecepatan. Pada kecepatan $3 \mathrm{~m} / \mathrm{s}$ memiliki penurunan paling tinggi dibanding kecepatan yang lainnya. Hal ini menunjukkan bahwa kadar uap air yang diterima udara terus berkurang dari waktu sebelumnya. Pada kecepatan $3 \mathrm{~m} / \mathrm{s}$ penurunan nilai humidity ratio $(\Delta \omega)$ lebih tinggi bila dibandingkan dengan variasi kecepatan $2,5 \mathrm{~m} / \mathrm{s}$ dan $2 \mathrm{~m} / \mathrm{s}$. Kecepatan $3 \mathrm{~m} / \mathrm{s}$ pada menit ke-1 memiliki nilai humidity ratio $(\Delta \omega)$ sebesar $6,24 \mathrm{~g} / \mathrm{kg}$, kecepatan $2,5 \mathrm{~m} / \mathrm{s}$ memiliki nilai humidity ratio $(\Delta \omega)$ sebesar $6,62 \mathrm{~g} / \mathrm{kg}$, dan kecepatan $2 \mathrm{~m} / \mathrm{s}$ memiliki nilai humidity ratio $(\Delta \omega)$ sebesar 6,64.

Pada menit ke-1 sampai menit ke-6 terjadi penurunan relative humidity yang cukup signifikan. Hal ini terjadi karena proses pengeringan yang maksimal terjadi pada menit tersebut. Kadar air yang masih tinggi pada batubara menyebabkan uap air mudah berpindah ke udara. Pada menit ke-23 selisih relative humidity relatif konstan. Hal ini menandakan proses pengeringan hanya terjadi sedikit karena kadar air pada batubara tersisa sangat sedikit sehingga uap air yang berpindah ke udara juga sangat sedikit.

E. Pengaruh Kecepatan Terhadap Moisture Content Fungsi Drying Time

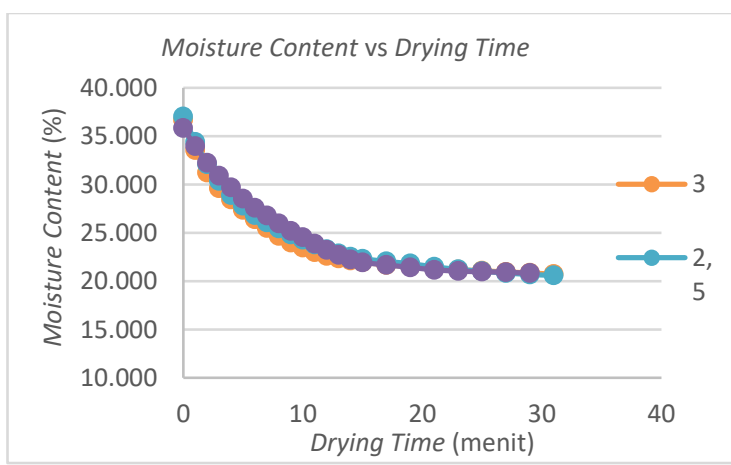

Gambar 8. Grafik pengaruh kecepatan terhadap moisture content fungsi drying rate
Moisture content merupakan perbandingan berat air yang terkandung dalam suatu bahan dengan berat kering bahan tersebut. Untuk menentukan moisture content biasanya digunakan basis basah. Pada gambar 8 menunjukkan grafik pengaruh kecepatan terhadap mositure content fungsi drying time. Pada menit ke-0 kecepatan $3 \mathrm{~m} / \mathrm{s}$ terjadi penurunan nilai moisture content dari $36,655 \%$ menjadi $20,712 \%$, kecepatan $2,5 \mathrm{~m} / \mathrm{s}$ terjadi penurunan nilai moisture content dari 37,023\% menjadi $20,588 \%$, dan kecepatan $2 \mathrm{~m} / \mathrm{s}$ terjadi penurunan nilai moisture content dari 35,827 \% menjadi $20,712 \%$.

Pada kecepatan $3 \mathrm{~m} / \mathrm{s}$ memiliki penurunan moisture content paling cepat hal ini dikarenakan kecepatan mempengaruhi Reynolds Number, dimana semakin tinggi kecepatan maka Reynolds Number juga akan semakin besar. Hal ini menyebabkan aliran semakin turbulen sehingga kontak udara pengering dan batubara akan lebih sering terjadi yang menyebabkan perpindahan massa akan semakin besar yang berarti moisture content yang terlepas ke udara juga akan semakin banyak.

\section{F. Pengaruh Kecepatan Terhadap Drying Rate Fungsi Drying Time}

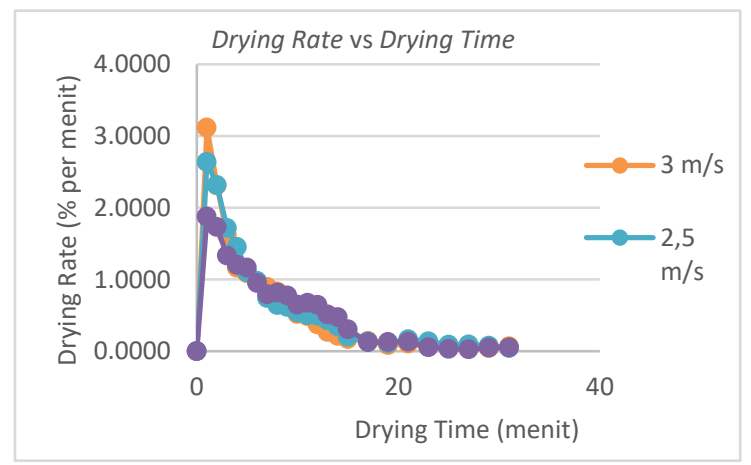

Gambar 9. Grafik pengaruh kecepatan terhadap drying rate fungsi drying time

Pada gambar 9 menunjukkan grafik drying time fungsi waktu dengan variasi kecepatan $3 \mathrm{~m} / \mathrm{s}, 2,5 \mathrm{~m} / \mathrm{s}$ dan $2 \mathrm{~m} / \mathrm{s}$. Trendline pada ketiga grafik tersebut menunjukan penurunan nilai drying rate yang signifikan pada menit ke-1 hingga menit ke- 8 . Pada kecepatan $3 \mathrm{~m} / \mathrm{s}$ memiliki nilai drying rate sebesar 3,1182\% per menit, kecepatan $2,5 \mathrm{~m} / \mathrm{s}$ memiliki nilai drying rate sebesar $2,638 \%$ per menit, dan kecepatan $2 \mathrm{~m} / \mathrm{s}$ memiliki nilai drying rate sebesar $1,9806 \%$ per menit. Setelah menit ke-8 penurunan sudah tidak lagi signifikan dan setelah menit ke-17 besar drying rate menunjukan nilai yang konstan.

Nilai drying rate terbesar terjadi pada kecepatan $3 \mathrm{~m} / \mathrm{s}$. Moisture content akan cepat berkurang pada menit awal yaitu sampai menit ke-8 kemudian menunjukkan nilai yang konstan setelah menit ke-17. Nilai yang konstan pada drying rate dikarenakan moisture content yang tersisa pada batubara hanya sedikit sehingga massa uap air yang berpindah ke udara juga akan semakin sedikit. Dari grafik drying rate ini digunakan untuk mengetahui besarnya moisture content yang dilepas batubara ke udara tiap satuan waktu. 
G. Pengaruh Kecepatan Terhadap Perbandingan Uap Air yang Dilepas Batubara dan Diserap Udara

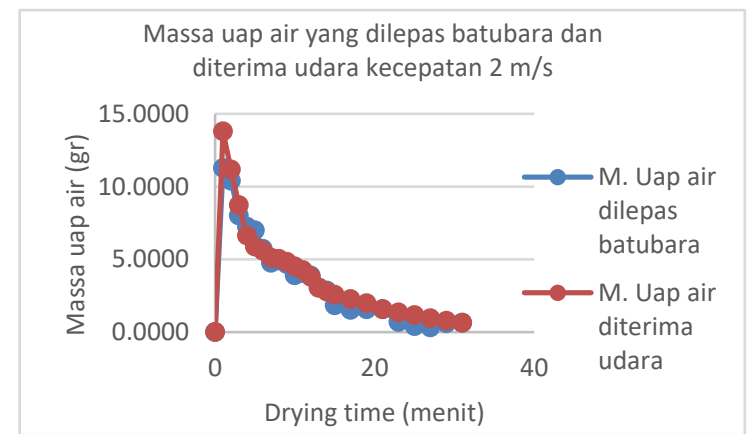

Gambar 10. Grafik perbandingan massa uap air yang dilepas batubara dan diserap udara fungsi drying time pada kecepatan $2 \mathrm{~m} / \mathrm{s}$

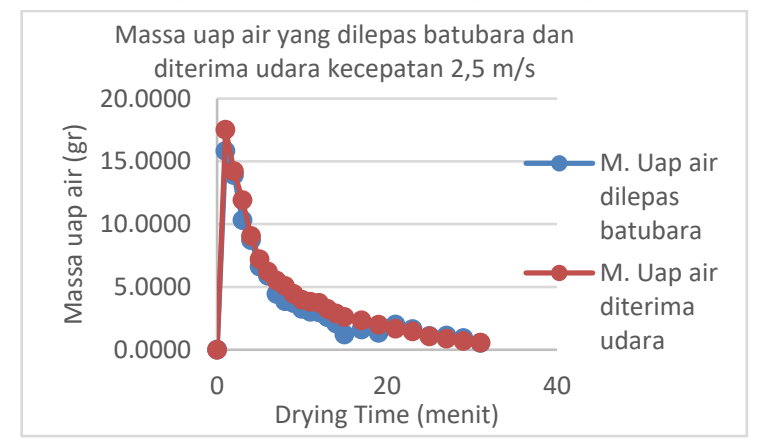

Gambar 11. Grafik perbandingan massa uap air yang dilepas batubara dan diserap udara fungsi drying time pada kecepatan $2,5 \mathrm{~m} / \mathrm{s}$

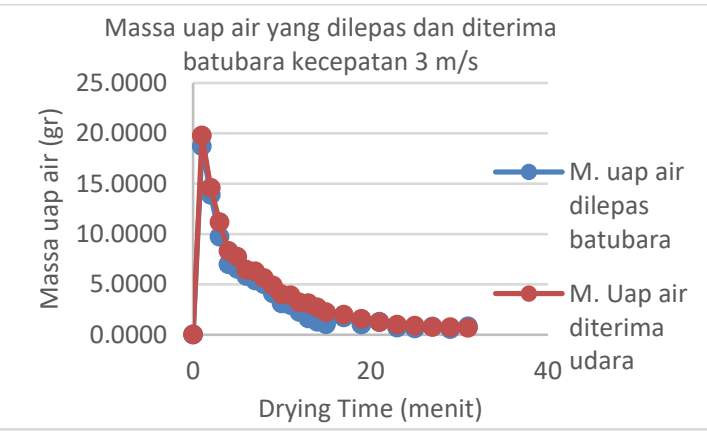

Gambar 12. Grafik perbandingan massa uap air yang dilepas batubara dan diserap udara fungsi drying time pada kecepatan $3 \mathrm{~m} / \mathrm{s}$

Pada grafik dapat dilihat bahwa besarnya uap air yang dilepas oleh batubara memiliki trendline menurun. Selain itu besarnya uap air yang diterima oleh udara memiliki trendline menurun pula. Hal ini menandakan bahwa telah terjadi proses perpindahan massa dari batubara menuju udara pengering. Pada menit pertama pengeringan hingga menit kelimabelas, penurunan uap air yang dilepas batubara cukup signifikan. Namun pada menit selanjutnya massa uap air yang dilepas cenderung kontan dan jumlahnya kecil. Ini menandakan bahwa jumlah uap air yang tersisa dibatubara sudah menipis dan hanya menyisakan di bagian dalam atau pori sehingga lebih sulit untuk keluar. Pada menit awal, perbandingan jumlah uap air yang dilepas batubara dan diterima udara kecepatan $3 \mathrm{~m} / \mathrm{s}$ lebih banyak jika dibangkan kecepatan $2,5 \mathrm{~m} / \mathrm{s}$ dan $2 \mathrm{~m} / \mathrm{s}$

Secara teori besarnya uap air yang dilepas batubara dan diserap udara adalah sama, namun terjadi ketidaksamaan antara uap air yang dilepas oleh batubara dan diterima oleh udara dapat disebabkan oleh beberapa hal. Bila dilihat dari sisi uap air yang dilepas oleh batubara, ketidaksamaan ini bisa disebabkan oleh ketidakseragaman moisture content awal yang dimiliki oleh tiap partikel batubara. Selain itu faktor bentuk juga memungkinkan perbedaan ini. Bentuk batubara yang tidak seragam juga mempengaruhi jumlah uap air yang dilepas oleh batubara. Bila dilihat dari sisi udara pengering, ketidaksamaan dapat diakibatkan kesalahan pembacaan alat ukur.

\section{KESIMPULAN}

Berdasarkan eksperimen yang telah dilakukan dalam menguji alat swirling fluidized bed coal dryer dengan variasi kecepatan inlet udara pengering dapat disimpulkan:

1. Kecepatan $3 \mathrm{~m} / \mathrm{s}$ memiliki nilai penurunan relative humidity paling tinggi yaitu dari 54,7 \% pada menit ke-1 menuju 24,6 \% pada menit ke-31. Penurunan relative humidity dikarenakan massa uap air yang berpindah ke udara dari batubara semakin banyak pada kecepatan $3 \mathrm{~m} / \mathrm{s}$ jika dibandingkan dengan kecepatan 2,5 m/s dan $2 \mathrm{~m} / \mathrm{s}$.

2. Kecepatan $3 \mathrm{~m} / \mathrm{s}$ memiliki selisih kenaikan temperatur paling tinggi, yaitu dari temperatur 33,4 ${ }^{\circ} \mathrm{C}$ pada menit ke-1 menuju temperatur $40,6{ }^{\circ} \mathrm{C}$ pada menit ke-31. Selisih paling tinggi ini dikarenakan pada kecepatan $3 \mathrm{~m} / \mathrm{s}$ moisture content pada batubara lebih cepat menguap sehingga temperatur outlet akan hampir sama dengan temperatur inlet.

3. Kecepatan $3 \mathrm{~m} / \mathrm{s}$ memiliki nilai penurunan humidity ratio paling besar dibanding dengan kecepatan 2,5 $\mathrm{m} / \mathrm{s}$ dan kecepatan $2 \mathrm{~m} / \mathrm{s}$.

4. Kecepatan $3 \mathrm{~m} / \mathrm{s}$ dapat mengurangi moisture content batubara awal sebesar 36,655 \% menjadi 20,712\%. Kecepatan 2,5 m/s dapat mengurangi moisture content batubara awal sebesar 37,023\% menjadi $20,558 \%$. Kecepatan $2 \mathrm{~m} / \mathrm{s}$ dapat mengurangi moisture content batubara awal sebesar 35,827 \% menjadi $20,712 \%$.

5. Kecepatan $3 \mathrm{~m} / \mathrm{s}$ memiliki nilai drying rate sebesar $3,1182 \%$ per menit. Kecepatan 2,5 m/s memiliki nilai drying rate sebesar $2,638 \%$ per menit. Kecepatan 2 $\mathrm{m} / \mathrm{s}$ memilki nilai drying rate sebesar $1,9806 \%$ per menit.

6. Koefisien perpindahan panas paling besar terjadi pada kecepatan $3 \mathrm{~m} / \mathrm{s}$ dengan nilai 86,1744 W/m².K. Kecepatan 2,5 m/s memiliki koefisien perpindahan panas sebesar 79,5205 W/m².K. Kecepatan $2 \mathrm{~m} / \mathrm{s}$ memiliki koefisien perpindahan panas sebesar $71,4939 \mathrm{~W} / \mathrm{m}^{2} . \mathrm{K}$

7. Koefisien perpindahan massa paling besar terjadi pada kecepatan $3 \mathrm{~m} / \mathrm{s}$ dengan nilai $0,078264 \mathrm{~m} / \mathrm{s}$. Kecepatan 2,5 m/s memiliki nilai koefisien perpindahan massa sebesar $0,072052 \mathrm{~m} / \mathrm{s}$. Kecepatan $2 \mathrm{~m} / \mathrm{s}$ memiliki nilai koefsien perpindahan massa sebesar $0,065203 \mathrm{~m} / \mathrm{s}$.

\section{UCAPAN TERIMA KASIH}

Penulis mengucapkan terima kasih kepada Prof. Dr. Eng. Ir. Prabowo, M.Eng, selaku dosen pembimbing yang telah banyak memberi masukan dan bimbingan selama proses pengerjaan tugas akhir ini. Dan juga penulis berterima kasih pula kepada Prof. Dr. Ir. Djatmiko Ichsani, M.Eng., Ary Bachtiar K. P., ST. MT. PhD., Dr. Bambang Sudarmanta, ST, MT., selaku dosen penguji tugas akhir, atas masukan dan saran terhadap tugas akhir ini. 


\section{DAFTAR PUSTAKA}

[1] http://www.akhman.net/fungsi-dan-prinsip-kerja-pltu/.

[2] Wahyu. Analisis Pola Pengoperasian mill pulverizer di PLTU I Jawa Tengah Rembang. 2013. Teknik Mesin. Universitas Diponegoro. Semarang, Indonesia.

[3] Levy, Edward K., Sarunac, Bilirgen \& Caram. 2006. Use of Coal Drying To Reduce Water Consumed in Pulverized Coal Power Plants. Energy Research Center Lehigh University. Bethlehem. Moran MJ, Shapiro HN. Fundamentals of Engineering Thermodynamics. John Wiley \& Sons Inc.; 2006.
[4] Hyun-Seok Kim, Yohsuke Matsushita, Motohira Oomori, Tatsuro Harada, Jin Miyawaki, Seong-Ho Yoon \& Isao Mochida. 2013. Fluidized Bed Drying of Loy Yang Brown Coal with Variation of Temperature, Relative Humidity, Fluidization Velocity and Formulation of its Drying Rate. Kyushu University. Japan.

[5] Incropera, Frank, DeWitt. 2007. Fundamentals of Heat and Mass Transfer $6^{\text {th }}$ Edition. John Wiley \& Sons Inc. New York.

[6] Stoecker, Wilbert, Jones. 1982. Refrigeration and Air Conditioning, $2^{\text {nd }}$ Edition. McGraw-Hill Inc. Urbana-Champaign. 